\title{
PENGEMBANGAN MODEL INTERNALISASI NILAI- NILAI PENDIDIKAN AGAMA SEBAGAI UPAYA UNTUK MENANGKAL POTENSI TERORISME DAN GEJALA DISINTEGRASI BANGSA
}

\author{
Oleh: \\ Estu Miyarso \\ Staf Pengajar FIP UNY
}

\begin{abstract}
Penelitian ini bertujuan untuk mengetahui persepsi masyarakat tentang terorisme dan mengetahui analisis kebutuhan pendidikan anti terorisme di sekolah sebagai langkah awal dalam mengembangkan model internalisasi nilai-nilai pendidikan agama (Universalitas Islam atau Islam Kaffah) di sekolah untuk menangkal potensi terorisme dan gejala disintegrasi bangsa. Metode penelitian ini menggunakan Research and Development. Subjek dan lokasi penelitian ini adalah siswa SLTA di wilayah Yogyakarta. Teknik sampling yang digunakan adalah purposive sampling. Sesuai target penelitian pada tahun pertama (tahun 2010), dari hasil penelitian pengembangan ini diketahui bahwa: (1) persepsi masyarakat tentang terorisme beragam. Paling tidak, ada tiga pandangan yang berbeda bagaimana masyarakat mempersepsikan tentang terorisme (2) Hasil need assesment mengungkapkan responden setuju perlunya pendidikan anti terorisme di sekolah dan dimasukan sebagai kurikulum baik dalam kegiatan intrakurikuler atau kegiatan ekstrakurikuler. Bentuk kurikulum yang diterapkan bisa secara integrasi dengan pelajaran lain maupun secara mandiri melalui kegiatan di luar jam pelajaran. (3) dihasilkannya prototype model internalisasi nilai pendidikan agama (Islam Universal atau Islam Kaffah) dalam bentuk draft modul pendidikan anti terorisme di sekolah yang perlu ditindaklanjuti dengan ujivalidasi ahli dan uji coba dalam penelitian berikutnya.
\end{abstract}

\section{PENDAHULUAN}

Pendidikan adalah usaha sadar dan terencana untuk mewujudkan suasana belajar dan proses pembelajaran agar peserta didik secara aktif mengembangkan potensi dirinya untuk memiliki 
Pengembangan Model Internalisasi Nilai-Nilai Pendidikan Agama sebagai Upaya untuk Menangkal Potensi Terorisme dan Gejala Disintegrasi Bangsa

(Estu Miyarso)

kekuatan spiritual keagamaan, pengendalian diri, kepribadian, kecerdasan, akhlak mulia, serta keterampilan yang diperlukan dirinya, masyarakat, bangsa dan negara (UU Sisdiknas No.20 Tahun 2003). Secara eksplisit maupun implisit orientasi penyelenggaraan sistem pendidikan nasional tersebut sangat menekankan pada upaya pengembangan pendidikan nilai (moral) dan akhlak mulia para pelakunya.

Praktek pendidikan yang mengesampingkan unsur nilai, moral, dan akhlak mulia pada akhirnya justru akan membawa manusia sebagai pelaku pendidikan dalam kondisi kehidupan yang sekitarba tidak nyaman. Hal ini dapat dilihat dari gejala degradasi moral masyarakat yang semakin memprihatinkan antara lain lunturnya sifat jujur, amanah, rasa tanggung jawab, disiplin, serta integritas diri terhadap kehidupan bermasyarakat dan berbangsa. Bahkan, demoralisasi dan dehumanisasi telah menjadi gejala umum dalam kehidupan di Indonesia. Hal ini ditandai dengan tingginya angka korupsi, tingginya tingkat kerusakan lingkungan alam, tingginya angka kriminalitas, serta maraknya aksi kekerasan dalam bentuk teror termasuk upaya separatisme di negeri ini.

Ironisnya, pelajaran atau perkuliahan agama sebagai basis pendidikan nilai selama ini dinilai hanya berorientasi pada angka, hafalan ayat, sejarah, dan informasi tentang agama yang lebih mengedepankan aspek kognitif daripada aspek afektif dan moralitas hingga menjadi perilaku (psikomotorik) sehari-hari. Di sisi yang lain, "sakralisasi" agama tanpa ada ruang dialektika yang lebih egaliter terjadi pada lembaga pendidikan yang berbasis agama. Akibatnya, banyak out put pendidikan yang tahu tentang ilmu agama tetapi gagap dalam menyesuaikan dengan kehidupan nyata. Bahkan bagi kalangan tertentu, agama (Islam) telah menjadi justifikasi untuk melakukan aksi teror maupun separatisme yang selalu muncul silih berganti meskipun para pelakunya banyak yang telah ditangkap dan dihukum mati. Dari asumsi dan beberapa fakta tersebut, peneliti tertarik untuk mengangkat masalah tentang model internalisasi nilai pendidikan agama (universalitas Islam atau Islam 
Kaffah) sebagai upaya untuk menangkal potensi terorisme dan gejala disintegrasi bangsa yang terus muncul dan terjadi di masyarakat.

\section{Kajian Tentang Pendidikan dan Nilai-Nilai Islam}

Pendidikan merupakan aspek terpenting dalam kehidupan manusia. maka setiap usaha pendidikan sebaiknya dilandasi oleh nilai-nilai ideal (Ideal core values) dan berlaku secara umum (General Pattern). Dalam pelaksanaannya, pendidikan memerlukan dasar nilai-nilai ideal yang dapat menjadi sumber kebenaran dan kekuatan yang dapat mengantarkan pada apa yang dicita-citakan. Dasar tersebut juga harus menjadi standar nilai dalam mengevaluasi aktivitas pendidikan yang diselenggarakan.

Menurut Munir Yusuf (2010) dalam Persfektif Islam, pandangan hidup yang mendasari seluruh proses pendidikan Islam adalah pandangan hidup yang Islami yaitu nilai-niai luhur yang bersifat transendental, eternal dan universal.

Lebih jauh Ilham J. Aburrauf (2008) memaparkan bahwa dalam Islam, keimanan merupakan sebuah manhajul hayah (sistem hidup) yang akan senantiasa membawa seorang muslim untuk kembali kepada ajaran agamanya. Segala permasalahan akan diupayakan untuk ditinjau dari "kaca mata" Islam. Bagaimana Islam mendudukkan persoalan tertentu, demikian pula seorang muslim akan mendudukkan persoalan tersebut.

Salah satu kutipan ayat al-Qur'an yang menjadi landasan pelaksanaan pendidikan Islam, sebagai Ideal Core Values, misalnya QS. Ali Imran : 110, yang artinya:

"Kaти adalah umat yang terbaik yang dilahirkan untuk manusia, menyuruh kepada yang ma'ruf, dan mencegah dari yang munkar, dan beriman kepada Allah. sekiranya ahli Kitab beriman, tentulah itu lebih baik bagi mereka, di antara mereka ada yang beriman, dan kebanyakan mereka adalah orangorang yang fasik" ( QS. Ali Imran: 110). 
Bahkan Allah Ta'ala secara lebih tegas berfirman dalam QS Al Maidah ayat 3 yang artinya: "Pada hari ini telah aku sempurnakan untuk kamu agamamu, dan telah aku cukupkan kepada kamu nikmat-Ku, dan Aku telah ridhai Islam itu jadi agama bagimu”.

Seorang guru atau tenaga pendidik muslim, sebelum dia berperan sebagai guru atau tenaga pendidik, dia adalah seorang muslim. Artinya, dia akan memenuhi panggilan hati nuraninya untuk senantiasa membawa misi Islam dalam kehidupannya. Dan misi Islam itu adalah: “rahmatan lil 'alamin”. Meletakkan wacana pendidikan dalam bingkai ajaran Islam, tentu juga bukan sesuatu yang aneh. Sebab, para nabi dan rasul 'alaihimus shalatu was salam sendiri, yang merupakan manusia-manusia figur keagamaan, adalah guru-guru kehidupan. Tugas pokok dan misi utama mereka adalah pendidikan dan pengajaran. Mereka adalah tokoh-tokoh pendidikan.

\section{Ruang Lingkup Terorisme}

\section{Pengertian Terorisme}

Kata Terorisme berasal dari Bahasa Perancis le terreur yang semula dipergunakan untuk menyebut tindakan pemerintah hasil Revolusi Perancis yang mempergunakan kekerasan secara brutal dan berlebihan dengan cara memenggal 40.000 orang yang dituduh melakukan kegiatan anti pemerintah. Selanjutnya kata Terorisme dipergunakan untuk menyebut gerakan kekerasan anti pemerintah di Rusia. Dengan demikian kata Terorisme sejak awal dipergunakan untuk menyebut tindakan kekerasan oleh pemerintah maupun kegiatan yang anti pemerintah (Wikipedia Indonesia, 2010).

Kata teror secara harfiah berarti usaha menciptakan ketakutan, kengerian, dan kekejaman oleh seseorang atau golongan. Teroris adalah orang yang menggunakan kekerasan untuk menimbulkan rasa takut, biasanya untuk tujuan politik. Terorisme adalah penggunaan kekerasan untuk menimbulkan ketakutan dalam usaha mencapai tujuan politik (Kamus Besar Bahasa Indonesia dalam Marzuki, 2010). 
Tindak pidana teroris diartikan bahwa setiap orang yang dengan sengaja menggunakan kekerasan atau ancaman kekerasan menimbulkan suasana teror atau rasa takut terhadap orang secara meluas atau menimbulkan korban yang bersifat massal, dengan cara merampas memerdekaan atau hilangnya nyawa dan harta benda orang lain, atau mengakibatkan kerusakan atau kehancuran terhadap obyek-obyek vital yang strategis atau lingkungan hidup atau fasilitas publik atau fasilitas internasional (UU No.15 tahun 2003 tentang Tindak Pidana Terorisme).

\section{Ciri-ciri dan Bentuk Terorisme}

Menurut Densus 88 AT POLDA DIY. (2010) ciri-ciri tindakan terorisme sebagai kejahatan luar biasa, antara lain:
a. Menghilangkan nyawa secara indiscriminatif (tanpa memandang korban)

b. Menimbulkan suasana teror, ketakutan secara luas atau menghilangkan kemerdekaan

c. Menimbulkan kerugian harta benda dengan dampak pada kehidupan ekonomi, sosial dan politik serta hub internasional

d. Terencana dan terorganisir (organized crime)

e. Mobilitas tinggi dan bersifat rahasia

Terorisme juga bisa berkarakteristik lain seperti halnya:

a. Ada maksimalisasi korban secara sangat mengerikan.

b. Keinginan untuk mendapatkan liputan di media massa secara internasional secepat mungkin.

c. Serangan terorisme itu tidak pernah bisa diduga karena sasarannya sama dengan luasnya seluruh permukaan bumi.

Modus Operandi tindakan terorisme bisa berupa apa saja dalam rangka mencapai tujuannya. Densus 88 AT POLDA DIY. (2010) mengidentifikasi beberapa modus operadi yang dilakukan para pelaku teror di Indoensia yaitu: ancaman bom melalui telepon, surat, email, bingkisan/ paket, penculikan dan penyanderaan baik terhadap tokoh atau masyarakat biasa, pembajakan transportasi, 
Pengembangan Model Internalisasi Nilai-Nilai Pendidikan Agama sebagai Upaya untuk Menangkal Potensi Terorisme dan Gejala Disintegrasi Bangsa

(Estu Miyarso)

penembakan gelap, sabotase, nobika, pelatihan kemiliteran, rekruitmen, peledakan bom, dan perampokan.

Bentuk dan Orientasi Teror menurut Marzuki, 2010:

a. Semangat Nasionalisme, seperti terorisme yang ada di Aljazair, Palestina, dan sejumlah negara jajahan di masa suburnya kolonialisme.

b. Semangat Separatisme, seperti gerakan IRA di Irlandia, Macan Tamil Ealam di Srilanka, SPLA di Sudan, MNLF di Philipina, dan Gerakan Aceh Merdeka, Republik Maluku Selatan atau Organisasi Papua Merdeka di Indonesia.

c. Semangat Radikalisme Agama, seperti kelompok jihad di Mesir, jihad di Yaman, National Islamic Front di Sudan, AlQaedah yang berbasis di Afganistan, Jamaah Islamiyah yang berbasis di Malaysia, atau kelompok-kelompok radikal Yahudi seperti Haredi, Gush Emunim, Kach Kabane di Israel.

d. Gerakan Terorisme yang didorong oleh Spirit Bisnis, seperti Narcoterorism di Myanmar yang dikenal dengan sebutan United War State, Yakuza di Jepang, yaitu organisasi di kalangan dunia hitam yang melakukan bisnis illegal dengan mengedepankan metode teror sebagai cara untuk mencapai tujuan.

\section{Terorisme dalam Islam}

Terorisme, dalam bahasa Arab, identik dengan kata alirhâb, mashdar yang merupakan musytaq (pecahan kata) dari fi'l (kata kerja) arhaba. Maknanya adalah "menciptakan ketakutan" (akhâfa) atau "membuat kengerian/kegentaran" (fazza'a) (MUI, 2005).

Dalam sejarah Islam, akar munculnya terorisme adalah dari paham sempalan khawarij (pemberontak). Suatu paham ekstrim dalam beragama, yang membuahkan sikap merasa benar sendiri, kemudian serampangan dalam memahami dan mengamalkan dalildalil syari'at lepas dari bimbingan para 'ulama, yang berujung kepada pengkafiran semua pihak yang bertentangan dengan 
pendapatnya, termasuk mengkafirkan pemerintah kaum muslimin (Luqman bin Muhammad Ba'abduh, 2009).

Gerakan terorisme khawarij yang pertama kali muncul dalam sejarah Islam adalah di akhir masa Khilafah 'Utsman bin 'Affan Radhiyallah 'anhu, yang diprakarsai oleh seorang Yahudi, Abdullah bin Saba', dengan menampilkan slogan keadilan dan benci kezhaliman. Sebagai korban pertama kali adalah sang khalifah Utsman bin 'Affan sendiri. Kemudian semakin gencar pada masa Kekhalifahan 'Ali bin Abi Thalib Radhiyallah 'anhu, yang beliau sendiri pun menjadi korban aksi pemberontakan tersebut. Merekalah kelompok sempalan khawarij, yang tumbuh menggerogoti dan menghancurkan Islam. Di atas paham mengkafirkan orang-orang yang bertentangan dengan mereka, dan berlanjut menghalalkan darah mereka. Terutama pemerintah muslimin, yang telah mereka vonis sebagai pemerintah kafir. Itu semua mereka lakukan atas nama agama.

Rasulullah Shallallahu 'alaihi wa Sallam jauh-jauh hari telah memberitakan kemunculan kelompok sesat ini, lengkap dengan ciri-ciri dan sifat-sifatnya. Rasulullah Shallallahu 'alaihi wa Sallam bersabda:

Akan keluar di akhir zaman suatu kaum yang muda-muda umurnya, pendek akalnya. Mereka mengatakan ucapan sebaikbaik manusia. Mereka membaca Al Qur'an, tapi tidak melewati kerongkongan mereka. Mereka melesat (keluar) dari (batasbatas) agama seperti melesatnya anak panah menembus binatang buruannya. [HR. Al Bukhari 3611, 5057, 6930; Muslim 1066]

Rasulullah Shallallahu 'alaihi wa Sallam menyifati mereka sebagai: "Mereka adalah sejahat-jahat makhluk". [HR. Muslim 1067]

Kaum muslimin tentu berlepas diri dari aksi-aksi teroris, karena aksi-aksi tersebut bertolak belakang dengan ajaran Rasulullah Shallallahu 'alaihi wa Sallam dan para sahabatnya. Allah 
Pengembangan Model Internalisasi Nilai-Nilai Pendidikan Agama sebagai Upaya untuk Menangkal Potensi Terorisme dan Gejala Disintegrasi Bangsa

(Estu Miyarso)

Subhanahu wa Ta'ala mengutus Nabi-Nya sebagai rahmat bagi alam semesta sebagaimana dalam firman-Nya:

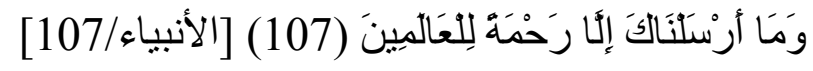

"Dan tiadalah Kami mengutus kamu, melainkan untuk (menjadi) rahmat bagi semesta alam. " (Al-Anbiya: 107)

Beliau adalah seorang nabi yang sangat memiliki kasih sayang dan kelembutan sebagaimana Allah Subhanahu wa Ta'ala sebutkan dalam firman-Nya:

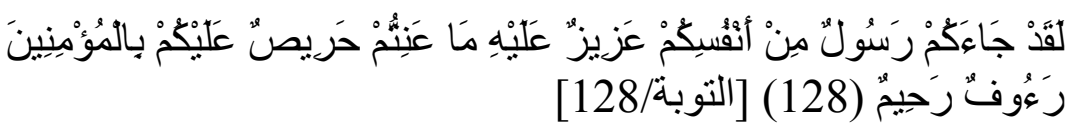

"Sungguh telah datang kepadamu seorang Rasul dari kaummu sendiri, berat terasa olehnya penderitaanmu, sangat menginginkan (keimanan dan keselamatan) bagimu, amat belas kasihan lagi penyayang terhadap orang-orang mukmin. " (AtTaubah: 128)

Bahkan dalam kondisi perang melawan orang kafir sekalipun, masih nampak sifat kasih sayang beliau. Sebagaimana pesan beliau kepada para komandan pasukan perang yang diriwayatkan oleh Sulaiman bin Buraidah, dari ayahnya, ia berkata:

"Adalah Rasulullah Shallallahu 'alaihi wa Sallam bila menetapkan seorang komandan sebuah pasukan perang yang besar atau kecil, beliau berpesan kepadanya secara khusus untuk bertakwa kepada Allah Subhanahu wa Ta'ala dan berbuat baik kepada kaum muslimin yang bersamanya, lalu beliau mengatakan:" 'Berperanglah dengan menyebut nama Allah, di jalan Allah. Perangilah orang yang kafir terhadap Allah. Berperanglah, jangan kalian melakukan ghulul (mencuri rampasan perang), jangan berkhianat, jangan mencincang mayat, dan jangan pula membunuh anak-anak. Bila kamu berjumpa dengan musuhmu dari kalangan musyrikin, maka 
ajaklah kepada tiga perkara. Mana yang mereka terima, maka terimalah dari mereka dan jangan perangi mereka. Ajaklah mereka kepada Islam, kalau mereka terima maka terimalah dan jangan perangi mereka...' (Shahih, HR. Muslim)

Dalam riwayat Ath-Thabarani (Al-Mu'jam Ash-Shaghir no. hadits 340):

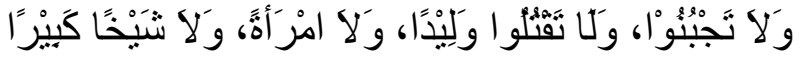

"Jangan kalian takut, jangan kalian membunuh anak-anak, jangan pula wanita, dan jangan pula orang tua."

Islam bahkan tidak membolehkan membunuh orang kafir kecuali dalam satu keadaan, yaitu manakala dia sebagai seorang kafir harbi (yang memerangi muslimin). Allah 1 berfirman, yang artinya:

"Allah tidak melarang kamu untuk berbuat baik dan berlaku adil terhadap orang-orang yang tiada memerangimu karena agama dan tidak (pula) mengusir kamu dari negerimu. Sesungguhnya Allah menyukai orang-orang yang berlaku adil. Sesungguhnya Allah hanya melarang kamu menjadikan sebagai kawanmu orang-orang yang memerangimu karena agama dan mengusir kamu dari negerimu, dan membantu (orang lain) untuk mengusirmu. Dan barangsiapa menjadikan mereka sebagai kawan, maka mereka itulah orang-orang yang zalim. “

\section{(Al-Mumtahanah: 8-9)}

Adapun jenis kafir yang lain, semacam kafir dzimmi yaitu orang kafir yang hidup di bawah kekuasaan dan jaminan penguasa muslim, atau kafir mu'ahad yaitu seorang kafir yang memiliki perjanjian keamanan dengan pihak muslim, atau kafir musta'min yaitu yang meminta perlindungan keamanan kepada seorang muslim, atau sebagai duta pihak kafir kepada pihak muslim, maka Nabi Shallallahu 'alaihi wa Sallam melarang membunuh mereka. 
Pengembangan Model Internalisasi Nilai-Nilai Pendidikan Agama sebagai Upaya untuk Menangkal Potensi Terorisme dan Gejala Disintegrasi Bangsa

(Estu Miyarso)

Bahkan mereka dalam jaminan keamanan dari pihak pemerintah muslimin.

Menurut Qomar ZA. (2008) aksi-aksi terorisme khawarij mengandung pelanggaran terhadap ajaran agama Islam yang mulia. Sebab diantaranya yaitu:

a. Membunuh manusia tanpa alasan dan cara yang benar

b. Menumbuhkan rasa ketakutan di tengah masyarakat

c. Merupakan sikap memberontak kepada penguasa muslim yang sah

d. Menyelewengkan makna jihad fi sabilillah yang sebenarnya

e. Membuat kerusakan di muka bumi

f. Merusak harta benda

g. Terorisme Khawarij adalah bid'ah, alias perkara baru yang diada-adakan dalam agama, sehingga merupakan kesesatan.

\section{Cara Penelitian}

Jenis penelitian yang dilaksanakan adalah Research and Development. Pendekatan yang dilakukan pada tahun pertama adalah penelitian survey dan pengembangan prototype model internalisasi nilai-nilai pendidikan agama Islam Kaffah. Subjek penelitian ini meliputi siswa-siswi SLTA sebagai subjek utama penelitian, guru sebagai pembina kegiatan model pendidikan anti terorisme dalam bentuk kegiatan ekstrakurikuler kerohanian Islam di sekolah dan mahasiswa sebagai fasilitator.

Pada prakteknya, data hasil analisis kebutuhan pendidikan anti terorisme di sekolah yang dijaring melalui instrumen angket penelitian disebar ke 15 SLTA di wilayah Yogyakarta dengan responden guru sebanyak 50 orang dan siswa sebanyak 100 orang adapun angket yang kembali dan diterima peneliti sebanyak 35 orang dari guru dan 65 orang dari siswa. Pada tahun pertama ini, metode penelitian lebih difokuskan pada survey persepsi masyarakat tentang terorisme dan analisis kebutuhan akan perlu tidaknya pendidikan anti terorisme di sekolah. Untuk itu, analisis data yang digunakan yaitu mendeskripsikan secara serempak baik secara 
kualitatif terutama data yang berkaitan dengan persepsi masyarakat tentang terorisme maupun secara kuantitatif berupa data yang diperoleh melalui penyebaran angket terbuka dan tertutup tentang analisis kebutuhan kepada guru dan siswa di 15 SLTA yang ada di wilayah Daerah Istimewa Yogyakarta.

\section{PEMBAHASAN}

Terorisme merupakan satu diantara tiga masalah faktual di Indonesia selain korupsi dan musibah bencana alam. Setidaknya, tiga masalah besar ini selalu hadir silih berganti menghiasi headline media massa baik cetak maupun elektronik yang beroperasi di negeri ini.

Pada umumnya, responden penelitian ini menyatakan bahwa terorisme dan disintegrasi bangsa keduanya secara etimologis dan terminologis pada dasarnya berbeda, namun dari sisi dampak bagi kehidupan berbangsa dan bernegara kurang lebih sama, yaitu sebagai anasir yang mengganggu harmoni (disharmoni) dan social order kehidupan berbangsa dan bernegara. Bahkan dalam beberapa kasus, aksi teror digunakan oleh para separatis untuk memisahkan diri dari Republik ini.

Adapun data hasil analisis secara kualitatif mengenai persepsi responden dari civitas akademika kampus UNY tentang terorisme secara lebih detail dapat diklasifikasi ke dalam tiga lapisan pandangan, yaitu:

Lapisan pertama, pandangan mereka mengenai isu terorisme diasosiasikan atau berpijak pada dampak negatif yang ditimbulkannya. Dampak negatif yang dimaksud terkait dengan kerugian materiil, moril, dan dampak psikologis dari aksi teror. Dosen, mahasiswa, maupun karyawan dalam lapisan ini menempatkan isu terorisme sebagai sesuatu yang sederhana saja, bahwa terorisme merupakan kegiatan yang merusak tatanan, menyebabkan kerusakan fisik, dan mendatangkan ketakutan secara psikologis. Dengan cara pandang ini, memberantas terorisme akan efektif 
Pengembangan Model Internalisasi Nilai-Nilai Pendidikan Agama sebagai Upaya untuk Menangkal Potensi Terorisme dan Gejala Disintegrasi Bangsa

(Estu Miyarso)

dengan tindakan represif. Misalnya, pengebom harus dilumpuhkan sebelum bom diledakkan.

Lapisan kedua adalah mereka yang secara analitik mengaitkan terorisme dengan unsur ruang yang memungkinkan atau menjadi faktor kausal bagi munculnya fenomena terorisme. Dalam pandangan mereka, terorisme tidak berdiri di ruang hampa. Ada faktor yang mendorong munculnya tindakan-tindakan yang menyebabkan kerugian materiil, kerugian jiwa, dan ketidaktenangan psikologis yang dilakukan oleh para teroris tersebut. Di samping itu terdapat unsur negara dan pemerintah yang memberikan ruang bagi terjadinya kejahatan terorisme atau paling tidak munculnya gerakan terorisme.

Sedangkan lapisan yang ketiga adalah mereka yang secara kritis merespon terorisme, dikaitkan dengan anatomi yang terlibat dalam isu terorisme dan berusaha menelaah kepentingan yang bermain di dalamnya. Terorisme dalam pandangan kritis bukan saja relasi utama antara aktor (pelaku) dengan ruang (negara), namun relasi sangat kompleks terkait dengan berbagai kepentingan yang tidak semuanya terlihat.

Dengan demikian, menjadi sangat penting artinya untuk memfungsikan kegiatan-kegiatan keislaman baik dalam kegiatan pelajaran atau perkuliahan agama Islam, kegiatan ekstrakurikuler kerohanian Islam baik di kampus maupun lingkungan sekolah. Hal ini menjadi bagian dari upaya meminimalisasi potensi terorisme dan disintegrasi bangsa dengan menggunakan konsep dan panji ajaran Islam sendiri secara kaffah (menyeluruh).

Deskripsi Data Hasil Analisis Kebutuhan Pendidikan Anti Terorisme di Sekolah

Kebutuhan Pendidikan Anti Terorisme menurut Guru dan Siswa

Pendidikan teroris adalah salah satu upaya prefentif yang dilakukan untuk memberikan bekal pemahaman hingga menjadi suatu keyakinan kepada masyarakat muslim tentang bahaya 
terorisme. Bahaya terorisme yang dikaji tidak sekedar menghindari resiko material dan non material yang bersifat duniawi tapi juga menghindari resiko penyimpangan akidah sebagai perwujudan keimanan dan ketakwaan seorang muslim yang mengemban misi Islam sebagai rahmat bagi seluruh alam "rahmatan lil alamin".

Berdasarkan persentase jumlah responden dan penilaian yang dipilih, data dari responden guru tersebut dapat disajikan dalam tabel dan diagram berikut ini:

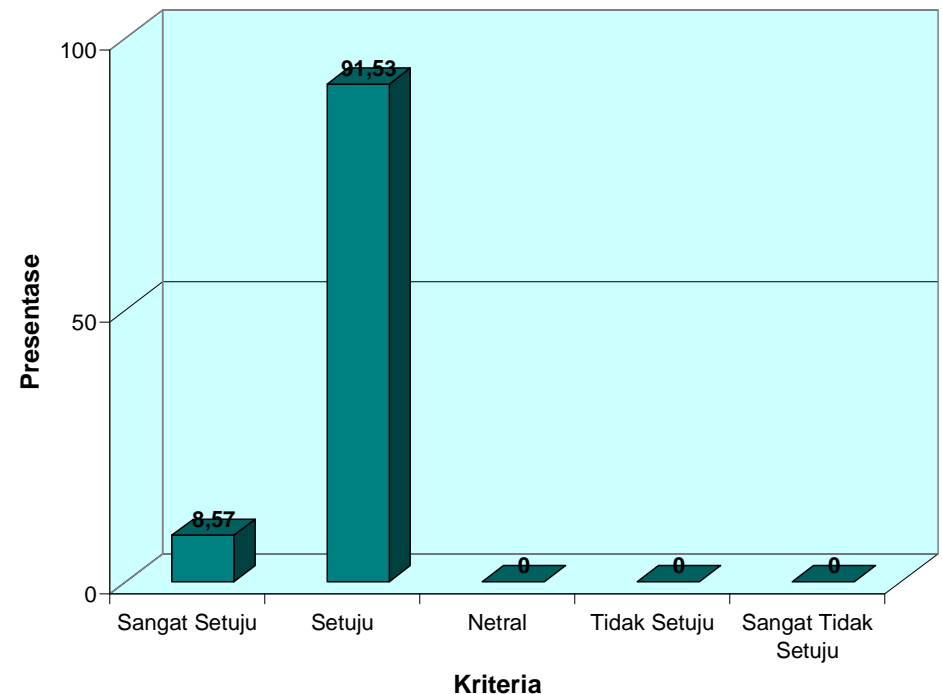

Gambar 1. Diagram Keburuhan Pendidikan Anti Teroris Berbasis Nilai-nilai Universalitas Islam di Sekolah (menurut guru)

Adapun data dari responden siswa tersebut dapat disajikan dalam tabel dan diagram berikut ini: 
Pengembangan Model Internalisasi Nilai-Nilai Pendidikan Agama sebagai Upaya untuk Menangkal Potensi Terorisme dan Gejala Disintegrasi Bangsa

(Estu Miyarso)

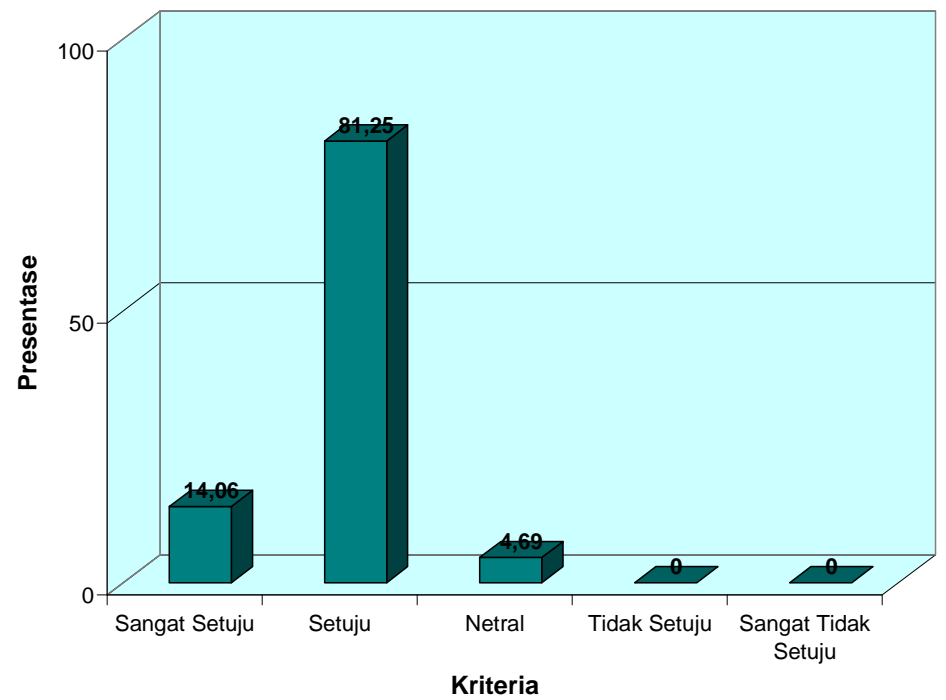

Gambar 2. Diagram Keburuhan Pendidikan Anti Teroris Berbasis Nilai-nilai Universalitas Islam di Sekolah (menurut siswa)

Berdasarkan tabel dan diagram batang di atas, hasil analisis kebutuhan pendidikan anti teroris berbasis nilai-nilai universalitas Islam di sekolah adalah bahwa dari 20 butir yang dinilai, diperoleh hasil sebagai berikut: 8,57\% responden guru dan 14,06\% responden siswa memilih Sangat Setuju, 91,43\% responden guru dan $81,25 \%$ responden siswa memilih setuju, $0 \%$ responden guru dan $4,69 \%$ responden siswa memilih netral, $0 \%$ responden guru dan siswa memilih tidak setuju, dan 0\% responden guru dan siswa memilih Sangat Tidak Setuju. Dengan demikian dapat disimpulkan bahwa dari hasil analisis kebutuhan pendidikan anti teroris berbasis nilainilai universalitas Islam di sekolah secara keseluruhan dengan responden guru menyatakan "Setuju".

Adapun alasan yang mendasari perlunya pendidikan anti teroris diterapkan di sekolah dapat dilihat dari data hasil 
penjaringan angket terbuka butir $3 c$ yaitu dari $56,25 \%$ responden yang menjawab belum paham tentang teroris atau terorisme hal tersebut disebabkan karena mereka memang tidak tertarik sebesar $27,78 \%$ dan yang menyatakan bahwa responden kurang penjelasan sebesar $72,22 \%$. Dari jawaban responden butir 4 pada angket terbuka mengenai ada tidaknya nara sumber yang pernah membahas tentang teroris atau terorisme di kelas maupun dalam kegiatan sekolah yaitu sebanyak $1,56 \%$ responden menyatakan $\mathrm{No}$ Comment, sebanyak 9,38\% responden menyatakan sudah pernah, dan sebanyak $89,06 \%$ responden guru dan siswa menyatakan belum pernah ada. Hal ini semakin memperkuat alasan mengapa pendidikan anti teroris memang perlu untuk diterapkan di sekolah.

\section{Bentuk Model Penerapan Kurikulum Pendidikan Anti Terorisme di Sekolah}

Dari pemaparan data-data diatas dapat ditarik suatu kesimpulan bahwa pelaksanaan model kurikulum pendidikan anti terorisme di sekolah dapat dilakukan dalam 3 bentuk, yaitu:

a. Bentuk kurikulum spasial atau terpisah secara rutin. Dalam hal ini materi-materi tentang pendidikan anti terorisme disusun dan diterapkan dalam aktivitas kegiatan ekstrakurikuler terutama kerohanian Islam yang dapat diselenggarakan secara rutin dan terprogram setiap minggu dalam beberapa kali pertemuan.

b. Bentuk kurikulum spasial atau terpisah secara insidental. Materi pendidikan anti terorisme disusun dan disampaikan dalam aktivitas dan kegiatan lain di luar jam mata pelajaran secara insidental baik pada saat upacara bendera, kegiatan masa orientasi siswa (MOS), maupun bimbingan konseling sesuai urgensi kebutuhannya. Pelaksanaan bentuk kurikulum ini bisa bersungsi sebagai pengantar atau sekaligus tindak lanjut dari pelaksanaan bentuk kurikulum spasial secara rutin.

c. Bentuk kurikulum integral. Materi pendidikan anti terorisme disusun dan disampaikan dalam aktivitas dan kegiatan lain di dalam jam pelajaran (intrakurikuler) yang dilaksanakan secara 
Pengembangan Model Internalisasi Nilai-Nilai Pendidikan Agama sebagai Upaya untuk Menangkal Potensi Terorisme dan Gejala Disintegrasi Bangsa

(Estu Miyarso)

integral pada mata pelajaran yang terkait terutama pada kelompok mata pelajaran pengembangan ahlak mulia dan kepribadian seperti pendidikan agama Islam maupun PKn. Pengintegrasian materinya meliputi pokok bahasan maupun sub pokok bahasan yang ada pada mata pelajaran tersebut yang sesuai dengan pembahasan tentang isu terorisme dan gejala disintegrasi bangsa.

\section{SIMPULAN}

1. Setidaknya ada tiga lapisan pandangan dari masyarakat terutama dari civitas kampus mengenai terorisme.

2. Guru dan siswa menganggap bahwa pendidikan anti teroris merupakan kebutuhan yang penting dan perlu untuk diterapkan di sekolah.

3. Bentuk kurikulum yang diharapkan responden yaitu:

a. Bentuk kurikulum spasial atau terpisah secara rutin melalui kegiatan ekstrakurikuler kerohanian Islam.

b. Bentuk kurikulum spasial atau terpisah secara insidental melalui beberapa kegiatan di luar jam pelajaran seperti upacara bendera, kegiatan masa orientasi siswa (MOS), maupun bimbingan konseling sesuai urgensi kebutuhannya

c. Bentuk kurikulum integral dalam mata pelajaran yang terkait terutama pada kelompok mata pelajaran pengembangan ahlak mulia dan kepribadian seperti pendidikan agama Islam maupun PKn.

\section{DAFTAR PUSTAKA}

Abdul Faruq Ayip Syafrudin. (2008). Meraih Kemuliaan dengan Islam. http://asysyariah.com/syariah.php. diunduh tanggal 23 Agustus 2010 
Abdurrahman Wahid.KH. (2009). Pengantar Editor. Ilusi Negara Islam (ekspansi gerakan Islam transnasional di Indonesia). Jakarta: The Wahid Institute

A Doni Koesoema. (2007). Pendidikan Karakter: Strategi Mendidik Anak di Zaman Globlal. Jakarta: PT. Grasindo

Agus Iswanto. (2006). Teologi Kritis di Masa Teror: Strategi Pendidikan Teologi Kritis. Yogyakarta: Jurnal Millah PPs. MMI. UII

Banks, J. A. (1977). Teaching Strategies for the Social Studies : Inguiry, Valuing, and Decision Making, Reading : Addison - Wesley Publishing

Capra, F. (1998). Titik Balik Peradaban : Sains, Masyarakat dan Kebangkitan Kebudayaan, Yogyakarta : Yayasan Bentang Budaya

Densus 88 AT POLDA DIY. (2010) Masalah Terorisme di Indonesia. Makalah disampaikan dalam Focused Group Discussion 9 Oktober 2010. Yogyakarta: Fakultas Ilmu Pendidikan UNY.

Estu Miyarso. (2010). Pendidikan Politik Mahasiswa (Studi Kasus Netralitas Ormawa UNY dalam Pemilu 2009). Proseding Seminar dan Diseminasi Hasil-hasil Penelitian. Yogyakarta: Lemlit UNY

Ilham J. Abdurrauf. (2008). Selamatkan Generasi Muda Dengan Pendidikan Islami. Makalah Seminar Nasional Pendidikan Islami Forum Ukhuwah Pemuda dan Mahasiswa Islam (FUAS) - BONE, Islamic Center Kab. Bone, Juli 2008 M.

Lickona, T. (1991) Educating for Character: How our Schools can Teach Respect and Responsibility, New York : Bantam Books 
Pengembangan Model Internalisasi Nilai-Nilai Pendidikan Agama sebagai Upaya untuk Menangkal Potensi Terorisme dan Gejala Disintegrasi Bangsa (Estu Miyarso)

Luqman bin Muhammad Ba'abduh. (2009). Agar Anak tidak Menjadi Teroris. http://www.merekaadalahteroris.com diunduh tanggal 21 Agustus 2010

(2005). Sebuah Tinjauan Syariat Mereka Adalah Teroris (Bantahan terhadap Buku Aku Melawan Teroris karya Imam Samudra). Malang: Pustaka Qaulan Sadida

Majelis Ulama Indonesia. (2005). Buku Saku Fatwa Majelis Ulama Indonesia tentang Terorisme. Jakarta: Majelis Ulama Indonesia

Marzuki. (2010). Islam, Jihad, dan Terorisme. Makalah disampaikan dalam Focused Group Discussion 9 Oktober 2010. Yogyakarta: Fakultas Ilmu Pendidikan UNY.

Munir Yusuf. (2010). Nilai-nilai Ajaran Islam sebagai Landasan Pendidikan. http://www.muniryusuf.com/author/admin diunduh tanggal 19 Agustus 2010

Pemerintah Republik Indonesia. (2003). Undang-undang Sistem Pendidikan Nasional No. 20 tahun. 2003. Jakarta: Presiden Republik Indonesia.

Pemerintah Republik Indonesia. (2003). Undang-undang Anti Teror. Jakarta: Presiden Republik Indonesia

Qomar, ZA. (2009). Menyikapi Aksi-Aksi Teroris Khawarij. http://www.merekaadalahteroris.com diunduh tanggal 21 Agustus 2010 